https://doi.org/10.48009/1_iis_2010_451-459

\title{
ONLINE SHOPPING FACTORS: AN ANALYSIS OF COLLEGE STUDENTS' EXPERIENCES BASED ON GENDER
}

\author{
Allen D. Truell, Ball State University, atruell@ bsu.edu \\ Melody Alexander, Ball State University, malexander@bsu.edu \\ Jensen J. Zhao, Ball State University, jzhao@bsu.edu \\ Sherry Woosley, Ball State University, sawoosley@bsu.edu
}

\begin{abstract}
Advances in Internet technologies have grown tremendously over the years. Not surprisingly, one application of these Internet technologies that has grown right along with them is that of online shopping. Indeed, a simple search of the academic database Business Source Premiere combining the terms "online" and "shopping" dated 2000 through 2010 returned over 19,000 citations. A review of selected citations revealed that a wide range of topics regarding online shopping have been explored by researchers. The purpose of this study is to build upon this earlier work and explore a variety of online shopping factors as experienced by college students. Specifically, the purposes of this study were (a) to determine for what items college students online shop, (b) to determine the reasons college students online shop, (c) to determine problems college student experience when they online shop, and (d) to determine reasons college students are hesitant to online shop. Differences based on gender were also explored during the study.
\end{abstract}

Keywords: E-Commerce; Internet

\section{INTRODUCTION}

Advances in Internet technologies have grown tremendously over the years. Not surprisingly, one application of these Internet technologies that has grown right along with them is that of online shopping. A review of the literature reveals considerable research regarding online shopping [1, $2,3,4,5,6,7,8,9,10,11,12,13,14,15,16,17,18$, $19,20,21,22,23,24]$. Selected research articles are discussed next with a focus on the studies including the variables college students and/or gender as they relate to online shopping.

Yang and Wu [22] examined online shoppers' decision-making by gender. In their study, they used the Consumer Styles Inventory to identify six online shopping decision-making styles: perfectionism, brand, novel-fashion, confused, brand-loyal, and impulsiveness. Study results indicated that

Volume XI, No. 1, 2010 differences between female and male online shoppers existed. Specifically, they found that female online shoppers' decision-making is dominated by novelfashion and male online shoppers' decision making is dominated by brand. The researchers suggested that directors of online shopping sites focus on novelfashion and brand issues for females and males, respectively. The result of this recommendation was expected to be a better adapted marketing mix.

Hui and Wan [10] studied the factors impacting online shopping behavior based on gender in Singapore. Specifically, they explored the five factors which measured the extent to which individuals are comfortable with not having a real shopping experience: convenience, security, personality, user experience, and prices. Study results revealed that female participants disliked not being able to experience the touch and feel absent in the online shopping experience. In a related study, Siyal, Chowdhry, and Rajput [17] explored the impact of socio-economic factors on the adoption of online shopping in Singapore. Specifically, the socio-economic factors explored were: age, gender, income, education, and Internet exposure. Results of their study did not offer enough evidence to show that the gender has any affect on a person's decision to shop online.

Seock and Bailey [14] examined factors associated with the online shopping orientation of college students based on gender. Specifically, the factors explored in their study were: shopping enjoyment, brand/fashion consciousness, price consciousness, shopping confidence, convenience/time consciousness, in-home shopping tendency, and brand/store loyalty. A finding of their study suggests gender differences in college students' shopping orientations. Specifically, female college students reported higher shopping enjoyment, brand/fashion consciousness and shopping confidence than did participating male college students. Seock and Bailey [14] postulated that female college students tend to seek excitement benefits while shopping. Female college students tended to be brand and fashion knowledgably and price sensitive. Male

Issues in Information Systems 
college students exhibited higher convenience/time consciousness than did participating female college students. Male college students tended to shop for clothes based on time savings and convenience.

Zhang, Prybutok, and Strutton [24] explored the impact of impulse purchasing behaviors during online shopping transactions based on gender. Results of their study found that males were more impulsive online shoppers than females. They also found that female and male online shoppers differed significantly with respect to online purchase frequency. Specifically, females were found to purchase online significantly less frequently than were male online shoppers. In a related study, Dholakia and Chiang [7] examined the concept of online shopping gender-specific stereotypes. They postulated that such stereotypes might be expected because shopping is considered a female activity while technology is considered to be in the male realm. Study participants were college students familiar with online shopping. Specifically, results confirmed the suspected stereotype of females as shoppers. This stereotype was reversed when the product purchased was technical and expensive. In addition, in terms of personality attributions, female shoppers were viewed as less technical, less spontaneous, and more reliable when compared to male shoppers. In another study, Dillon and Reif [8] examined the factors influencing online shoppers' purchases based on gender. Results of their study indicated that gender differences were significant for consumer risk. Specifically, male college students were influenced significantly less by consumer risk such as forms of payment, confidentiality, and credit card security than were female college students.

$\mathrm{Xu}$ and Paulins [18] explored the attitudes of college students toward online shopping for apparel products. Results of their study indicated that more than half of the respondents mentioned credit card security and return policy concerns. Limited social activities were also noted when shopping online for apparel products. About $30 \%$ of the participants were concerned about merchandise quality and customer service support. While about half of the respondents thought shopping online was convenient, only about $20 \%$ considered online item price as lower than that of items sold in traditional stores. About $50 \%$ of the respondents agreed that online shopping can offer more merchandise options than traditional shopping. Black [1] explored the variable gender in an assessment of eBay use. Black postulated that because of known differences between male and female consumers when they shop at traditional stores, similar difference might be expected to occur when shopping on eBay. Results of the study indicated that females are more likely to purchase on eBay, but males are more willing to pay higher prices. This finding suggests that bidding for items online may provide a different experience than merely purchasing products online. Since many females like to shop, and the excitement of the auction may replace the satisfactions of the traditional in store shopping experience. In addition, it was found that men tend to pay more per eBay transaction, more likely to make online shopping purchases, comfortable with the Internet, and willing to risk more money per purchase.

\section{NEED FOR THE STUDY}

A review of the literature revealed considerable research devoted to online shopping $[1,2,3,4,5,6$, $7,8,9,10,11,12,13,14,15,16,17,18,19,20,21$, 22, 23, 24]. Despite this considerable research, scholars have called for more studies regarding online shopping [2, 10, 14, 21, 22]. Specifically, Seock and Bailey [14] suggested that more study of college students' online shopping experiences was needed. Yang and Lester [19] suggested that further research is needed regarding gender differences and online shopping factors. Yang, Lester, and James [21] postulated that many variables impact the decision to shop online and that more study of these variables is needed. Hui and Wan [10] recommended that more study of demographic variables and their impact on online shopping is needed. Lastly, Chang and Samuel [2] stated the rapid growth of online shopping has created the need for a greater understanding of the association between shopper demographics and their online shopping behavior. Results of this study are expected to add to the online shopping literature gap as identified by these earlier researchers.

\section{PURPOSE}

The purposes of this study were (a) to determine for what items college students online shop, (b) to determine the reasons college students online shop, (c) to determine problems college student experience when they online shop, and (d) to determine reasons college students are hesitant to online shop. Differences based on gender were also explored during the study. Specifically, answers to the following four research questions were sought.

1. For what items do college students online shop?

Issues in Information Systems 
2. Is there a significant difference in for what items do college students online shop based on gender?

3. For what reasons do college students online shop?

4. Is there a significant difference in for what reasons do college students online shop based on gender?

5. What problems do college students report when they shop online?

6. Is there a significant difference in what problems college students report when they shop online based on gender?

7. What reasons do college students report for being hesitant to shop online?

8. Is there a significant difference in what reasons do college students report for being hesitant to shop online by gender?

\section{METHODOLOGY}

The study participants, data collection procedures, and data analysis are presented next.

\section{Participants}

College students enrolled in selected information systems courses housed in a college of business at a Midwestern university were recruited to participate in the study. Participating college students were offered a small Institutional Review Board (IRB) approved incentive for completing the study survey. Of the participating college students, 286 provided the usable data analyzed in this study. Of these 286 students, $138(48.3 \%)$ were female and $148(51.7 \%)$ were male, respectively.

\section{Data collection procedures}

College students enrolled in selected information systems courses housed in a college of business at a Midwestern university were invited to participate in the study following the approved IRB protocol. College students who agreed to participate were directed to an online surveying system. Participating college students were asked to read a welcome message explaining the purposes of the research and to check a box indicating that they agreed to take part in the study. For the purposes of this study, college students were asked to provide data regarding their
(1) gender, (2) items purchased when they online shop, (3) the reasons for which they online shop, (4) the problems experienced when they online shop, and (4) the reasons for being hesitant to online shop. The purchases during online shopping, problems experienced during online shopping, and reasons for being hesitant to engage in online shopping consisted of 44, 6, 6, and 7 items, correspondingly. In each case, participating college students were asked to select all that applied. These 44, 6, 6, and 7 items are outlined in Tables 1, 2, 3, and 4, respectively.

\section{Data analysis}

To answer research questions one, three, five, and seven, the descriptive statistics frequencies and percentages were used. To answer questions two, four, six, and eight and determine if differences based on gender existed, the non-parametric statistic ChiSquare was used to analyze each item. All tests of significance were conducted at $\alpha=.05$.

\section{RESULTS}

Results for each of the eight research questions follow.

\section{Research Question One}

Research question one sought to determine for what items do college students online shop. A review of the frequencies and percentages presented in Table 1 revealed that at least one participant had purchased each of the 44 items included in that part of the survey. The most frequently purchased item was clothing with $183(63.99 \%)$ of the participating college students making such a buy. Two items tied for being the least frequently purchased items at one each: pots and pans $(\mathrm{n}=1,0.35 \%)$ and security/alarm systems $(n=1,0.35 \%)$. The item most frequently purchased by male college student participants was electronics, TV, stereo with 85 $(57.40 \%)$ reporting having made such a buy. The item most frequently purchased by female college student participants was clothing with 103 (74.60\%) reporting having made such a buy. The frequencies and percentages associated with these analyses are presented in Table 1.

\section{Research Question Two}

Research question two sought to determine if there were significant differences in the items for what college students online shop based on gender. A review of Table 1 revealed that there were significant 
differences in college student online purchase patterns based on gender for $15(34.09 \%)$ of the 44 items included on the survey. Female participants reported significantly higher purchase frequencies on the following seven items: (1) airline tickets, (2) books (personal reading), (3) clothing, (4) cosmetics, (5) hotel reservations, (6) jewelry, gemstones, and (7) other travel (bus, train, boat tickets). Male participants reported significantly higher purchase frequencies on the following eight items: (1) automobile and/or auto supplies, (2) collectables, (3) computer hardware, (4) computer software, (5) electronics, TV, stereo, (6) sports events, (7) sports items, and (8) tools. The Chi-Square values associated with these analyses are presented in Table 1.

\section{Research Question Three}

Research question three sought to determine the reasons for which participating college students online shop. A review of Table 2 revealed that the most frequent reason for shopping online was convenience with $261(91.22 \%)$ of participants reporting that item. The least frequent reason for shopping online was variety of items with 142 $(49.65 \%)$ of participants selecting that item. For participating female college students, the most frequent reason for shopping online was convenience with $126(91.22 \%)$ of participating female college students reporting that item; the least frequent reason for shopping online was variety of items with 68 (49.28\%) of participating female college students selecting that item. For participating male college students, the most frequent reason for shopping online was convenience with 135 (91.22\%) of participating male college students reporting that item; the least frequent reason for shopping online was variety of items with $74 \quad(50.00 \%)$ of participating male college students selecting that item. The frequencies and percentages associated with these analyses are presented in Table 2.

\section{Research Question Four}

Research question four sought to determine if there were significant differences in the reasons why college students shop online based on gender. A review of Table 2 revealed that there was only one reason for shopping online that differed based on gender. Specifically, male participants $(n=96$, $64.86 \%$ ) reported the item lower prices significantly more frequently than did female participants $(n=69$, $50.00 \%$ ). The Chi-Square values associated with these analyses are presented in Table 2.

Volume XI, No. 1, 2010
[Insert Table 2 about here]

\section{Research Question Five}

Research question five sought to determine the problems college students experienced with online shopping. A review of Table 3 revealed that the majority of participants $(n=163,56.99 \%)$ had never had a problem while shopping online. The least frequently reported problem associated with shopping online was having a credit/debit card number stolen $(\mathrm{n}=4,1.40 \%)$. The frequencies and percentages associated with these analyses are presented in Table 3.

\section{Research Question Six}

Research question six sought to determine if there were significant differences in the problems college students experienced with online shopping based on gender. A review of Table 3 revealed that there were no significant differences in the problems experienced by college students based on gender. The Chi-Square values associated with these analyses are presented in Table 3 .

[Insert Table 3 about here]

\section{Research Question Seven}

Research question seven sought to determine the reasons college students were hesitant to participate in online shopping. A review of Table 4 revealed that the most frequently noted reason reported for being hesitant to participate in online shopping online was that they do not want to receive junk e-mail with $183(63.99 \%)$ of participating college students reporting that item. The least frequently noted reason for being hesitant to participate in online shopping was that they no desire to shop online with 5 (1.75\%) of participants reporting that item. For participating female college students, the most frequent reason for being hesitant to shop online was they don't want to receive junk e-mail with $93(62.84 \%)$ reporting that item; the least frequent reason for hesitant to shop online was they have no desire to shop online with 3 $(2.10 \%)$ selecting that item. For participating male college students, the most frequent reason for being hesitant to shop online was did not want to receive junk e-mail with $90(65.22 \%)$ of participating male college students reporting that item; the least frequent reason for being hesitant to shop online was they have no desire to shop online with 2 (1.35\%) selecting that item. The frequencies and percentages 
associated with these analyses are presented in Table 4.

\section{Research Question Eight}

Research question eight sought to determine if there were significant differences in the reasons why college students shop online based on gender. A review of Table 4 revealed that there was only one reason for being hesitant to participate in online shopping based on gender. Specifically, female participants $(n=51,36.96 \%)$ reported the item do not trust the security significantly more frequently than did male participants $(\mathrm{n}=33,22.30 \%)$. The ChiSquare values associated with these analyses are presented in Table 4.

[Insert Table 4 about here]

\section{CONCLUSION AND DISCUSSION}

The 286 participants in this study were college students enrolled in selected information systems courses housed in a college of business at a Midwestern university. As such, the conclusion is put forward with that limitation acknowledged. Thus, it is concluded that there are significant differences in selected online shopping factors based on college student gender. This conclusion is supported by data in Tables 2, 3, and 4 .

Results of this are in agreement with the results reported by other researchers in that there are significant differences in online shopping factors based on gender $[1,7,10,14,18,22,24]$. Specifically, the results of this study are in agreement with the research of Yang and $\mathrm{Wu}$ [22] in that they found differences between female and male online shoppers. More expressly, they found that female online shoppers' decision-making is dominated by novel-fashion and male online shoppers' decision making is dominated by brand. In addition, Hui and Wan [10] found that female participants disliked not being able to experience the touch and feel absent in the online shopping experience. Seock and Bailey [14] reported gender differences in college students' shopping orientations. Specifically, female college students reported higher shopping enjoyment, brand/fashion consciousness and shopping confidence than did participating male college students. Female college students tended to be brand and fashion knowledgably and price sensitive. Male college students exhibited higher convenience/time consciousness than did participating female college students. Male college students tended to shop for

Volume XI, No. 1, 2010 clothes based on time savings and convenience. Zhang, Prybutok, and Strutton [24] also found that female and male online shoppers differed significantly with respect to online purchase frequency. Expressly, females were found to purchase online significantly less frequently than were males online shoppers. In a related study, Dholakia and Chiang [7] found support for the concept of online shopping gender-specific stereotypes. Specifically, results confirmed the suspected stereotype of females as shoppers. This stereotype was reversed when the product purchased was technical and expensive. In addition, in terms of personality attributions, female shoppers were viewed as less technical, less spontaneous, and more reliable when compared to male shoppers. In another study, Dillon and Reif [8] noted the factors influencing online shoppers' purchases based on gender were significant. Expressly, male college students were influenced significantly less by consumer risk such as forms of payment, confidentiality, and credit card security than were female college students. $\mathrm{Xu}$ and Paulins [18] found that more than half of college students in their study mentioned credit card security and return policy concerns. Limited social activities were also noted when shopping online for apparel products. About $30 \%$ of the participants were concerned about merchandise quality and customer service support. While about half of the respondents thought shopping online was convenient, only about $20 \%$ considered online item price as lower than that of items sold in traditional stores. About $50 \%$ of the respondents agreed that online shopping can offer more merchandise options than traditional shopping. Lastly, Black [1] found that females are more likely to purchase on eBay, but males are more willing to pay higher prices. In addition, it was found that men tend to pay more per eBay transaction, more likely to make online shopping purchases, comfortable with the Internet, and willing to risk more money per purchase.

\section{RECOMMENDATIONS FOR FUTURE RESEARCH}

Based on the results of this study and a review of the literature, the following recommendations for future research are offered.

1. The results of this study are based on data provided by 286 college students enrolled in selected information systems courses housed in a college of business at a Midwestern university who were recruited to participate in the research. 
Thus, more studies of factors influencing college students' online shopping is needed to confirm or to refute the results of this study.

2. This study involving college students explored the items purchased when they online shop, the reasons for which they online shop, the problems experienced when they online shop, and the reasons for being hesitant to online shop. The study survey consisted of 44, 6, 6, and 7 items, respectively. It is recommended that more comprehensive lists of items be developed. Expanding the number of items in each of the four areas explored in this study will provide for a more inclusive analysis.

3. Advances in Internet technologies have grown considerably over the years. All indications are that advances in Internet technologies will continue into the foreseeable future. Thus, studies of how future Internet technologies might impact the online shopping of college students and others is recommended.

\section{REFERENCES}

1. Black, G. S. (2005). Is eBay for everyone? An assessment of consumer demographics. SAM ADVANCED MANAGEMENT JOURNAL, 70(1), 50-59.

2. Chang, J., \& Samuel, N. (2004). Internet shopper demographics and buying behavior in Australia. The Journal of American Academy of Business, 5(1/2), 171-176.

3. Changchit, C. (2006). Consumer perceptions of online shopping. Issues in Information Systems, 7(2), 177-181.

4. Chug, C. C., \& Chang, S. (2005). Discussion on the behavior intention model of consumer online shopping. Journal of Business Management, 11, 41-57.

5. Comegys, C., Hannula, M., \& Väisänen, J. (2006). Longitudinal comparison of Finnish and US online shopping behavior among university students: The five-stage buying decision process. Journal of Targeting, Measurement and Analysis for Marketing, 14(4), 336-356.

6. Cowart, K. O., \& Goldsmith, R. E. (2007). The influence of consumer decision-making styles on online apparel consumption by college students.

Volume XI, No. 1, 2010
International Journal of Consumer Studies, 31, 639-647.

7. Dholakia, R. R., \& Chiang, K. (2003). Shoppers in cyberspace: Are they from Venus or Mars and does it matter? Journal of Consumer Psychology, 13(1\&2), 171-176.

8. Dillion, T. W., \& Reif, H. L. (2004). Factors influencing consumers' e-commerce commodity purchases. Information Technology, Learning, and Performance Journal, 22(2), 1-12.

9. Everard, A., \& Galletta, D. F. (2005-6). How presentation flaws affect perceived site quality, trust, and intention to purchase from an online store. Journal of Management Information Systems, 22(3), 55-95.

10. Hui, T., \& Wan, D. (2007). Factors affecting Internet shopping behavior in Singapore: Gender and educational issues. International Journal of Consumer Studies, 31, 310-316.

11. Kamis, A. A., \& Davern, M. J. (2005). An exploratory model of decision quality and its antecedents for category novices using multiplestage shopping engines. e-Service Journal, 4(1), 3-27.

12. McCloskey, D. (2003-2004). Evaluating electronic commerce acceptance with the technology acceptance model. Journal of Computer Information Systems, 42(2), 49-57.

13. Peslak, A. R., \& Bhatnagar, N. (2009). A review of Internet shopping factors: Do the Technology Acceptance Model or Theory of Reasoned Action Model apply? Issues in Information Systems, 10(2), 495-504.

14. Seock, Y., \& Bailey, L. R. (2008). The influence of college students' shopping orientations and gender differences on online information searches and purchase behaviors. International Journal of Consumer Studies, 32, 113-121.

15. Seock, Y., \& Chen-Yu, J. H. (2007). Website evaluation criteria among US college student consumers with different shopping orientations and Internet channel usage. International Journal of Consumer Studies, 31, 204-212.

Issues in Information Systems 
16. Siyal, M. Y., Chowdhry, B. S., \& Rajput, A. Q. (2006). Socio-economic factors and their influence on the adoption of e-commerce by consumers in Singapore. International Journal of Information Technology \& Decision Making, 5(2), 317-329.

17. Tabatabaei, M. (2009). Online shopping perceptions of offline shoppers. Issues in Information Systems, 10(2), 22-26.

18. Xu, Y., \& Paulins, V. A. (2005). College students' attitudes toward shopping online for apparel products. Journal of Fashion Marketing and Management, 9(4), 420-433.

19. Yang, B., \& Lester, D. (2004). Attitudes toward buying online. CyberPsychology \& Behavior, 7(1), 85-91.

20. Yang, B., \& Lester, D. (2005). Gender differences in e-commerce. Applied Economics, 37, 2077-2089.
21. Yang, B., Lester, D., \& James, S. (2007). Attitudes toward buying online as predictors of shopping online for British and American respondents. CyberPsychology \& Behavior, 10(2), 198-203.

22. Yang, C., \& Wu, C. (2007). Gender and Internet consumers' decision-making. CyberPsychology \& Behavior, 10(1), 86-91.

23. Yu, T., \& Wu, G. (2007). Determinants of Internet shopping behavior: An application of reasoned behavior theory. International Journal of Management, 24(4), 744-762.

24. Zhang, X., Prybutok, V. R., \& Strutton, D. (2007). Modeling influences on impulse purchasing behaviors during online marketing transactions. Journal of Marketing Theory and Practice, $\quad$ 15(1), 79-89. 
Table 1 Items For Which College Students Online Shop Based On Gender

\begin{tabular}{|c|c|c|c|c|}
\hline & $\begin{array}{c}\text { Female } \\
\text { Frequency } / \%\end{array}$ & $\begin{array}{c}\text { Male } \\
\text { Frequency } / \%\end{array}$ & $\begin{array}{c}\text { Total } \\
\text { Frequency } / \% \\
\end{array}$ & Chi-Square \\
\hline Clothing & $103(74.60 \%)$ & $80(54.10 \%)$ & $183(63.99 \%)$ & $13.10 / 0.00 *$ \\
\hline Airline tickets & $82(59.40 \%)$ & $69(46.60 \%)$ & $151(52.80 \%)$ & $4.69 / 0.03 *$ \\
\hline Banking & $79(57.20 \%)$ & $72(48.60 \%)$ & $151(52.80 \%)$ & $2.12 / 0.15$ \\
\hline Music & $69(50.00 \%)$ & $68(45.90 \%)$ & $137(47.90 \%)$ & $0.47 / 0.49$ \\
\hline Electronics, TV, stereo & $44(31.90 \%)$ & $85(57.40 \%)$ & $129(45.10 \%)$ & $18.83 / 0.00 *$ \\
\hline Entertainment (concert/movie tickets) & $69(50.00 \%)$ & $60(40.50 \%)$ & $129(45.10 \%)$ & $2.58 / 0.11$ \\
\hline Hotel Reservations & $76(55.10 \%)$ & $50(33.80 \%)$ & $126(44.06 \%)$ & $13.13 / 0.00 *$ \\
\hline Books (textbooks) & $65(47.10 \%)$ & $56(37.80 \%)$ & $121(42.31 \%)$ & $2.51 / 0.11$ \\
\hline Sports items & $36(26.10 \%)$ & $77(52.00 \%)$ & $113(39.51 \%)$ & $20.11 / 0.00 *$ \\
\hline Movies & $43(31.20 \%)$ & $54(36.50 \%)$ & $97(33.92 \%)$ & $0.90 / 0.34$ \\
\hline Books (personal reading) & $53(38.40 \%)$ & $39(26.40 \%)$ & $92(32.17 \%)$ & $4.76 / 0.03 *$ \\
\hline Sports events & $24(17.40 \%)$ & $55(37.20 \%)$ & $79(27.62 \%)$ & $13.96 / 0.00 *$ \\
\hline Computer software & $25(18.10 \%)$ & $53(35.80 \%)$ & $78(27.27 \%)$ & $11.27 / 0.00 *$ \\
\hline Pizza/fast food delivery & $43(31.20 \%)$ & $31(20.90 \%)$ & $74(25.87 \%)$ & $3.88 / 0.05$ \\
\hline Amusement Park Tickets & $39(28.30 \%)$ & $33(22.30 \%)$ & $72(25.17 \%)$ & $1.35 / 0.25$ \\
\hline Computer hardware & $17(12.30 \%)$ & $39(26.40 \%)$ & $56(19.58 \%)$ & $8.93 / 0.00 *$ \\
\hline Photography, supplies/camera & $25(18.10 \%)$ & $20(13.50 \%)$ & $45(15.73 \%)$ & $1.14 / 0.29$ \\
\hline Other travel (bus, train, boat tickets) & $30(21.70 \%)$ & $10(6.80 \%)$ & $40(13.99 \%)$ & $13.33 / 0.00 *$ \\
\hline Toys & $19(13.80 \%)$ & $20(13.50 \%)$ & $39(13.64 \%)$ & $0.00 / 0.95$ \\
\hline Rental car & $22(15.90 \%)$ & $16(10.80 \%)$ & $38(13.29 \%)$ & $1.63 / 0.20$ \\
\hline Send flowers & $19(13.80 \%)$ & $19(12.80 \%)$ & $38(13.29 \%)$ & $0.05 / 0.82$ \\
\hline Jewelry, Gemstones & $29(21.00 \%)$ & $8(5.40 \%)$ & $37(12.94 \%)$ & $15.45 / 0.00 *$ \\
\hline Collectibles & $10(7.20 \%)$ & $27(18.20 \%)$ & $37(12.94 \%)$ & $7.67 / 0.01 *$ \\
\hline Cosmetics & $31(22.50 \%)$ & $3(2.00 \%)$ & $34(11.89 \%)$ & $28.47 / 0.00 *$ \\
\hline Automobiles and/or auto supplies & $6(4.30 \%)$ & $25(16.90 \%)$ & $31(10.84 \%)$ & $11.63 / 0.00 *$ \\
\hline Health (vitamins, prescriptions) & $9(6.50 \%)$ & $17(11.50 \%)$ & $26(9.09 \%)$ & $2.13 / 0.14$ \\
\hline Personal care & $12(8.70 \%)$ & $13(8.80 \%)$ & $25(8.74 \%)$ & $0.00 / 0.98$ \\
\hline Cruise Reservations & $14(10.10 \%)$ & $9(6.10 \%)$ & $23(8.04 \%)$ & $1.60 / 0.21$ \\
\hline Office supplies & $11(8.00 \%)$ & $11(7.40 \%)$ & $22(7.69 \%)$ & $0.03 / 0.86$ \\
\hline Tools & $3(2.20 \%)$ & $19(12.80 \%)$ & $22(7.69 \%)$ & $11.44 / 0.00 *$ \\
\hline Insurance & $5(3.60 \%)$ & $14(9.50 \%)$ & $19(6.64 \%)$ & $3.92 / 0.05$ \\
\hline Exercise equipment & $9(6.50 \%)$ & $6(4.10 \%)$ & $15(5.24 \%)$ & $0.88 / 0.35$ \\
\hline Furniture & $6(4.30 \%)$ & $9(6.10 \%)$ & $15(5.24 \%)$ & $0.43 / 0.51$ \\
\hline Contacts & $8(5.80 \%)$ & $6(4.10 \%)$ & $14(4.90 \%)$ & $0.47 / 0.50$ \\
\hline Pet products & $4(2.90 \%)$ & $4(2.70 \%)$ & $8(2.80 \%)$ & $0.01 / 0.92$ \\
\hline Dolls, doll houses & $5(3.60 \%)$ & $1(0.70 \%)$ & $6(2.10 \%)$ & $3.02 / 0.08$ \\
\hline Pottery, glass, china & $4(2.90 \%)$ & $1(0.70 \%)$ & $5(1.75 \%)$ & $2.05 / 0.15$ \\
\hline Gourmet items & $3(2.20 \%)$ & $1(0.70 \%)$ & $4(1.40 \%)$ & $1.16 / 0.28$ \\
\hline Antiques and art & $3(2.20 \%)$ & $0(0.00 \%)$ & $3(1.05 \%)$ & $3.25 / 0.07$ \\
\hline Coins and stamps & $0(0.00 \%)$ & $3(2.00 \%)$ & $3(1.05 \%)$ & $2.83 / 0.09$ \\
\hline Cleaning supplies & $1(0.70 \%)$ & $1(0.70 \%)$ & $2(0.70 \%)$ & $0.00 / 0.96$ \\
\hline Groceries & $1(0.70 \%)$ & $1(0.70 \%)$ & $2(0.70 \%)$ & $0.00 / 0.96$ \\
\hline Pots and pans & $0(0.00 \%)$ & $1(0.70 \%)$ & $1(0.35 \%)$ & $0.94 / 0.33$ \\
\hline Security/alarm systems & $0(0.00 \%)$ & $1(0.70 \%)$ & $1(0.35 \%)$ & $0.94 / 0.33$ \\
\hline
\end{tabular}

Note: *Significant at alpha $=.05$. 
Online Shopping Factors

Table 2 Reason College Students Online Shop Based On Gender

\begin{tabular}{lcccc}
\hline & $\begin{array}{c}\text { Female } \\
\text { Frequency/\% }\end{array}$ & $\begin{array}{c}\text { Male } \\
\text { Frequency/\% }\end{array}$ & $\begin{array}{c}\text { Total } \\
\text { Frequency/\% }\end{array}$ & Chi-Square \\
\hline Convenience & $126(91.30 \%)$ & $135(91.22 \%)$ & $261(91.26 \%)$ & $0.00 / 0.98$ \\
Item not in stores & $93(67.39 \%)$ & $91(61.49 \%)$ & $184(64.34 \%)$ & $1.09 / 0.30$ \\
Lower prices & $69(50.00 \%)$ & $96(64.86 \%)$ & $165(57.69 \%)$ & $6.47 / 0.01 *$ \\
Easy to compare prices & $69(50.00 \%)$ & $90(60.81 \%)$ & $159(55.59 \%)$ & $3.38 / 0.07$ \\
Better selection & $73(52.90 \%)$ & $78(52.70 \%)$ & $151(52.80 \%)$ & $0.00 / 0.97$ \\
Variety of items & $68(49.28 \%)$ & $74(50.00 \%)$ & $142(49.65 \%)$ & $0.02 / 0.90$ \\
\hline
\end{tabular}

Note: *Significant at alpha $=.05$.

Table 3 Problems College Students Experience When They Online Shop Based On Gender

\begin{tabular}{lcccc}
\hline & $\begin{array}{c}\text { Female } \\
\text { Frequency/\% }\end{array}$ & $\begin{array}{c}\text { Male } \\
\text { Frequency/\% }\end{array}$ & $\begin{array}{c}\text { Total } \\
\text { Frequency/\% }\end{array}$ & Chi-Square \\
\hline Never had problems & $72(52.17 \%)$ & $91(61.49 \%)$ & $163(56.99 \%)$ & $2.53 / 0.11$ \\
Items delivered were late & $39(28.26 \%)$ & $37(25.00 \%)$ & $76(26.57 \%)$ & $0.39 / 0.53$ \\
Did not receive exactly what & & & & \\
$\quad$ was ordered & $33(23.91 \%)$ & $23(15.54 \%)$ & $56(19.58 \%)$ & $3.18 / 0.08$ \\
Items damaged & $12(8.70 \%)$ & $17(11.49 \%)$ & $29(10.14 \%)$ & $0.61 / 0.44$ \\
Items ordered never arrived & $11(7.97 \%)$ & $14(9.46 \%)$ & $25(8.74 \%)$ & $0.2 / 0.66$ \\
Credit/debit card number stolen & $2(1.45 \%)$ & $2(1.35 \%)$ & $4(1.40 \%)$ & $0.01 / 0.94$ \\
\hline
\end{tabular}

Note: *Significant at alpha $=.05$.

Table 4 Reasons College Students Are Hesitant To Online Shop Based On Gender

\begin{tabular}{|c|c|c|c|c|}
\hline & $\begin{array}{c}\text { Female } \\
\text { Frequency } / \%\end{array}$ & $\begin{array}{c}\text { Male } \\
\text { Frequency } / \%\end{array}$ & $\begin{array}{c}\text { Total } \\
\text { Frequency } / \%\end{array}$ & Chi-Square \\
\hline Do not want to receive junk e-mail & $90(65.22 \%)$ & $93(62.84 \%)$ & $183(63.99 \%)$ & $0.18 / 0.68$ \\
\hline \multicolumn{5}{|l|}{ Do not want to give } \\
\hline personal information & $74(53.62 \%)$ & $70(47.30 \%)$ & $144(50.35 \%)$ & $1.14 / 0.29$ \\
\hline Do not trust the security & $51(36.96 \%)$ & $33(22.30 \%)$ & $84(29.37 \%)$ & $7.40 / 0.01 *$ \\
\hline \multicolumn{5}{|l|}{ I have no hesitations when } \\
\hline Do not have credit/debit card & et $19(13.77 \%)$ & $27(18.24 \%)$ & $\begin{array}{l}46(16.08 \%) \\
24(839 \%)\end{array}$ & $\begin{array}{l}1.06 / 0.30 \\
0.06 / 080\end{array}$ \\
\hline \multicolumn{5}{|l|}{ Do not know where to go to } \\
\hline Shop online & $7(5.07 \%)$ & $3(2.03 \%)$ & $10(3.5 \%)$ & $1.96 / 0.16$ \\
\hline Have no desire to shop online & $3(2.10 \%)$ & $2(1.35 \%)$ & $5(1.75 \%)$ & $0.28 / 0.60$ \\
\hline
\end{tabular}

Note: *Significant at alpha $=.05$. 